\title{
Therapeutic potentials and pharmacological properties of Talinum triangulare (Jacq.) Willd. in the treatment and management of diabetes mellitus and other conditions
}

\author{
Oluwafemi Omoniyi Oguntibeju \& Kunle Okaiyeto \\ Phytomedicine \& Phytochemistry Group, Department of Biomedical Sciences, Faculty of Health and Wellness Sciences, Cape Peninsula \\ University of Technology, Bellville 7535, South Africa \\ *Email: oguntibejuo@cput.ac.za
}

\section{ARTICLE HISTORY \\ Received: 29 March 2021 \\ Accepted: 02 July 2021 \\ Available online \\ Version 1: 05 September 2021 \\ Version 2: 05 February 2022}

\section{KEYWORDS}

Diabetes mellitus

Phytochemicals

Nutrients

Oxidative stress

Free radicals
ABSTRACT

There is a growing interest in the use of medicinal plants. Previously, the assumption was that the use of medicinal plants is peculiar to developing and poor nations. However, due to advances in technology, innovative and scientific research on medicinal plants, the trend has changed. The number of people using medicinal plants for various reasons has increased significantly in developed countries. Research studies have shown that several plants display antioxidant, antidiabetic, antimicrobial, anticancer and antiulcer activities and that these plants and their bioactive molecules play important role in retarding the progression of acute and chronic disease conditions such as bacterial infections, diabetes, hypertension and cancer. These and other factors have stimulated interest in documenting and investigating medicinal plants for their nutritional and therapeutic benefits. In addition, vegetables such as Talinum triangulare (Jacq.) Willd. are cheap and affordable sources of protein, vital amino acids, vitamins, minerals and carbohydrates. Used as supplements, vegetables provide tangible and correct proportions of nutrients and therapeutic ingredients. As part of the documentation of medicinal plants in Africa and contributing to the pool of knowledge in the field, this review examines the various potentials of $T$. triangulare. It is envisaged that it would stimulate further interest and research in the plant and medicinal plants in general.

\section{Introduction}

African indigenous leafy vegetables are readily consumed as a source of micronutrients, carbohydrates and proteins. Reports have shown that plants especially those consumed as vegetables in Africa are very rich in provitamin A, vitamins $C$ and $E$, essential amino acids and mineral elements. Interestingly, these vegetables serve both the poor and the rich, the educated and illiterate sector of the society and helping people to meet their nutritional, economic, cultural and medicinal needs $(1,2)$.

Plants either as parts of food or botanicals have been used to cure and treat various diseases for centuries and developing countries continue to rely heavily on medicinal plants as the principal source of therapies with over $80 \%$ of their population using medicinal plants to meet primary health care needs ( 3 , 4). Medicinal plants are commonly used in traditional medicine. Traditional medicine is an ancient medical practice with a record showing that it existed before the advent of the modern healthcare system. It is based on indigenous theories, knowledge, beliefs, culture, tradition and experience that have been preserved and passed down from one generation to another generation (5-8).

Medicinal plants with antidiabetic or hypoglycaemic activity used in developing nations of the world have been known to play a role especially in non-classical types of diabetes and malnutritionrelated diabetes $(9,10)$. A typical example of a such plant is Poterium spinosum (an iron-rich antidiabetic plant) used by nomadic people in the Middle East (11). It has been reported that consumption of the root of this plant for one to two months eliminated symptoms of diabetes for one year (12). The use of medicinal plants such as Medicago sativa leaves has been linked to high manganese content in South Africa. Interestingly, manganese chloride has been shown to elicit a hypoglycaemic condition in patients with insulin-dependent diabetes mellitus and manganese has been recognised as an important cofactor for ATP phosphorylation of the beta-subunit of the insulin receptor $(13,14)$.

(C) Oguntibeju \& Okaiyeto (2021). This is an open-access article distributed under the terms of the Creative Commons Attribution License, which permits unrestricted use, distribution and reproduction in any medium, provided the original author and source are credited (https://creativecommons.org/licenses/by/4.0/). 
T. triangulare is a herbaceous perennial plant, abundant in tropical regions as a leafy vegetable. It is reported to be one of the most important leafy vegetables in Nigeria. It is valuable in the preparation of various types of soup in Nigeria according to traditions and cultures. The leaves and shoots are usually consumed as a cooked (boiled or steamed) vegetable. They are rather soft and mucilaginous and should not be cooked for long. It is rich in vitamins, magnesium, calcium, iron, potassium and proteins; used in the treatment of bacterial infections, diabetes mellitus, obesity and cardiovascular disease $(2,15)$.

There is a growing interest in the use of medicinal plants and researchers are exploring the botanical resources in African countries with the aim of screening and identifying indigenous plants with antidiabetic potentials. This is very important as the incidence of diabetes mellitus continues to increase globally from 30 million in 1985 to 382 million in 2014 and may even become more prevalent if the factors promoting the incidence are not addressed urgently $(16,17)$. Although both type 1 and type 2 diabetes mellitus seem to be increasing, however, type 2 diabetes seems to be contributing a greater proportion to the global prevalence of diabetes. There is a close relationship between diabetes mellitus and cardiovascular disease and cardiovascular disease has been seen as the most predominant cause of mortality and morbidity in diabetic individuals (19-21). It has been reported that $40-60 \%$ of diabetic patients present an increased risk of cardiovascular disease (22). This review becomes necessary as the incidence of diabetes mellitus in Africa is escalating and the role of medicinal plants in general and that of $T$. triagulare in the management of diabetes is gaining more attention. It will also broaden our knowledge and provide information on the best practice which could be useful for future antidiabetic therapy development.

\section{Distribution, cultivation and harvesting of $T$. triangulare}

T. triangulare (Jacq.) Willd. is also called Talinum fruticosum (L.) Juss. It is an indigenous plant in Central America, Mexico, South America and the Caribbean (23). Its common names include Philippine spinach, Waterleaf, Ceylon spinach, Cariru, Surinam purslane, Florida spinach, Sweetheart Potherb fame flower and Lagos bologi (24). It is now widely cultivated as a medicinal and food crop in India, South America, other parts of Asia and Nigeria $(25,26)$. It is an herbaceous perennial plant with swollen roots and succulent stems measuring 30-100 cm tall with leaves spirally arranged almost opposite and mostly crowded at the top of the stem (Fig. 1). It is a fast-growing plant, producing flowers year-round and principally selfpollinating. The flowers are pink in colour; it is commonly propagated by seedling but could also be propagated by cuttings. It is widely grown in tropical regions including many West and Central African countries. It is cultivated in Nigeria and Cameroon by seedling and cuttings. There are approximately 500 species of the genus Talinum globally (27). $T$. triangulare is sensitive to cold conditions and its roots will rot when water is logging in the soil. This tenderness often makes it to appear growing wild only as an annual plant. It thrives in humid conditions in temperatures around $30{ }^{\circ} \mathrm{C}$, in rich compost, acidic, well-drained soil under partial shade. It can without heat and drought. It can be easily propagated from seeds and cuttings and planted either way. It is ready to be harvested after less than two months. It spreads so easily from seeds, that in some places it becomes an agricultural weed. The collection period of $T$. triangulare differs from one geographical location to another. For example, in some parts of India (Tamil Nadu state), the plants are usually harvested from January to April from cultivated farmer's fields or natural localities of nine different districts (28). In Nigeria, the plant is usually collected from the wild during the dry season when other more popular vegetables are scarce and expensive.

\section{Folkloric applications of T. triangulare}

T. triangulare is a popular green leafy vegetable that grows in the wild and seasonally in Nigeria and other West African countries. The leaves and stems are used as a vegetable (29). It is believed to have medicinal value and it has been traditionally used in the treatment of measles, sexually transmitted infections, inflammatory disease, diabetes mellitus, cardiovascular diseases and serve as a blood tonic (3032). In India, the leaf powder of the plant is mixed with boiled milk and used in the treatment and management of diabetes (33). It is used in the thickening of soup and increased the bulk of stews (34). It also has medicinal properties (35), where the roots are used as a tunic for general weakness, a possible substitute for ginseng, to treat inflammation and swelling in South East Asia (36). In Edo State, Nigeria, T. triangulare is used as a diuretic, and for the management of gastrointestinal disorders (37). It is also used to treat Schistosomiasis, scabies, fresh cuts, high blood pressure and anaemia (38).

\section{Biochemical composition of $T$. triangulare}

It has been reported that the crude protein content of T. triangulare compares favourably with that of cowpea, peanut and cashew nuts $(32,39)$. A report by other researchers showed that the crude protein content of $T$. triangulare leaves and stems are $29.4 \%$ and $13.4 \%$, respectively (40). Its moisture content is $30.52 \%$, fibre $(55.94 \%)$ with a $\mathrm{pH}$ of 5.8 and contain oxalate, saponin, tannins, alkaloids, flavonoid and polyphenols. Although, T. triangulare is high in oxalate (mostly in soluble form), blanching or cooking has been shown to significantly reduced it to $50 \%$. It also contains vitamin $\mathrm{C}$, beta-carotene, niacin, thiamine with vitamin $\mathrm{C}$ as the main vitamin ranging from 345-354 mg/100 g (41). The mineral composition of $T$. triangulare includes potassium, phosphorus, calcium, magnesium sodium, zinc, iron, copper (4143). The nutritive value of $T$. triangulare has made it possible to be used as supplementary feeds to livestock such as poultry, cattle, rabbits and swine (4446).

\section{Pharmacological activities of T. triangulare}

The plant extraction for folkloric uses is usually carried out with boiling water. However, several researchers have explored different organic solvents for plant extraction in the literature depending on the bioactive compounds being targeted may be polar or 


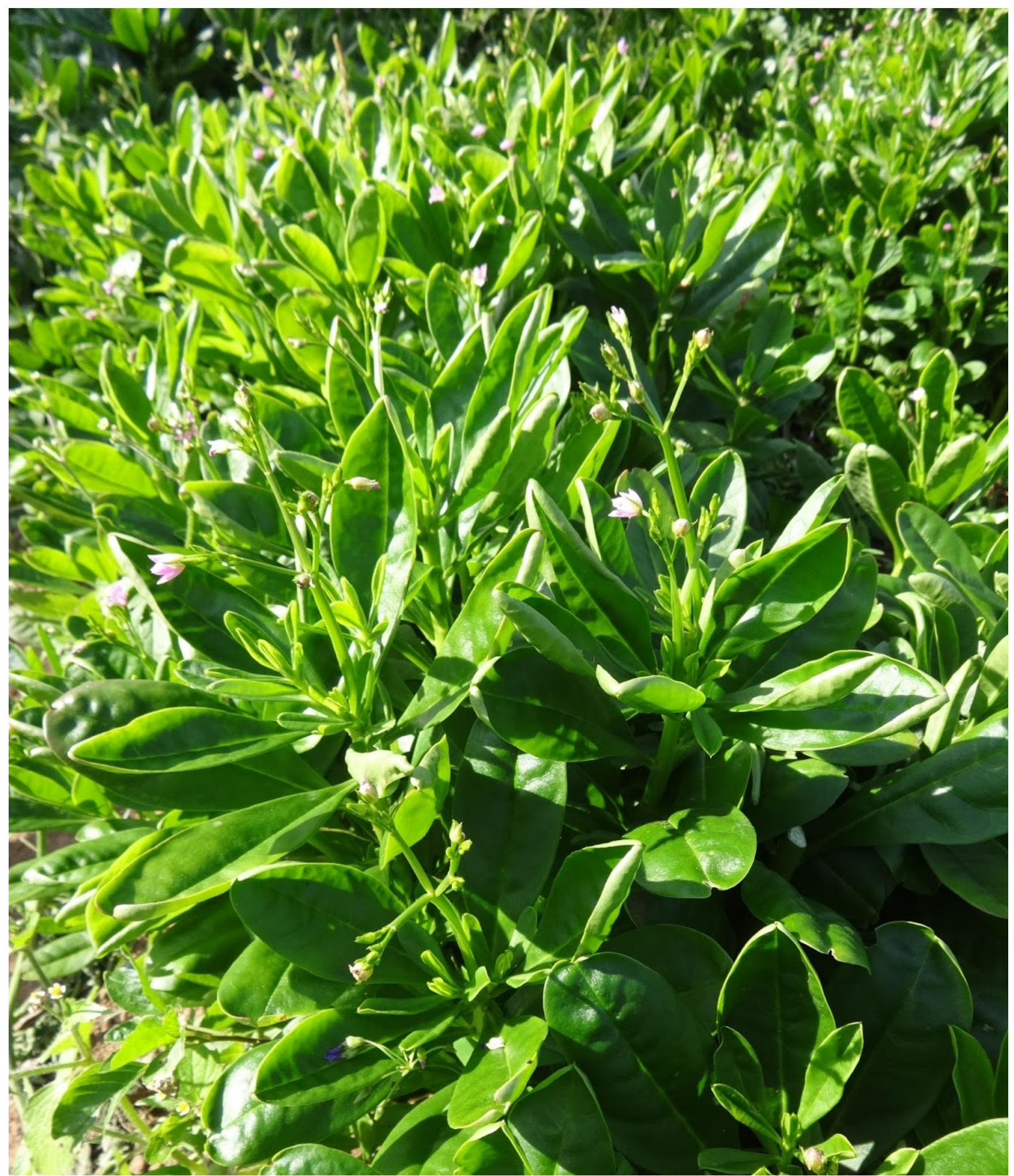

Fig. 1. Talinum triangulare. Source: www.tropical.thefrens.info.

non-polar compounds. Polar solvents are usually used to extract polar compounds and non-polar compounds for non-polar compounds. Previous studies have reported on the hepatoprotective effect (47) antidiabetic effect (48), antioxidant (49) and other biological activities (48) of $T$. triangulare. Reports are on the bioactive phytochemicals of the leaves of $T$. triangulare displaying various biological properties (50) (Fig. 2). Quercetin, one of the bioactive ingredients is shown to have analgesic, antiallergenic, antibacterial, antidiabetic, anti-inflammatory and antiviral activities (51). Some reported biological activities of $T$. triangulare are depicted in Table 1.

Antidiabetic and hypoglycaemic activity of $T$. triangulare

The role of medicinal plants in the treatment and management of various disease conditions is very important. This is because medicinal plants contain bioactive ingredients that allow them to play a key 
<smiles>Oc1cc(O)c2c(c1)O[C@H](c1ccc(O)c(O)c1)C(O)C2</smiles><smiles>Oc1ccc(/C=C/c2cc(O)cc(O)c2)cc1</smiles><smiles>O=c1c(-c2ccc(Cl)cc2)coc2cc(O)ccc12</smiles><smiles>O=c1c(O)c(-c2ccc(O)cc2)oc2cc(O)cc(O)c12</smiles><smiles>O=c1c(O)c(-c2ccc(O)c(O)c2)oc2cc(O)cc(O)c12</smiles><smiles>COc1cc(-c2oc3cc(O)cc(O)c3c(=O)c2O)ccc1O</smiles><smiles>C[C@@H]1OC(OCC2OC(Oc3c(-c4ccc(O)c(O)c4)oc4cc(O)cc(O)c4c3=O)C(O)C(O)C2O)[C@H](O)[C@@H](O)[C@H]1O</smiles><smiles>COc1cc(C(=O)O)ccc1O</smiles><smiles>COc1cc(/C=C/C(=O)O)ccc1O</smiles><smiles>COc1cc(CNC(=O)CCCC/C=C/C(C)O)ccc1O</smiles><smiles>O=C(O)/C=C/c1ccc(O)c(O)c1</smiles><smiles>O=C(O)/C=C/c1ccc(O)cc1</smiles>

Fig. 2. Some bioactive compounds identified from the aqueous extract of $T$. triangulare (50).

Table 1. Some reported biological activities of $T$. triangulare.

\begin{tabular}{|c|c|c|c|c|}
\hline Activity & Solvent & Assay & Target & Reference \\
\hline Diabetes & Ethanolic & In vivo & $\begin{array}{l}\text { Blood glucose, uric acid, creatinine, and total bilirubin } \\
\text { concentrations were significantly reduced, lower triglycerides, total } \\
\text { cholesterol, LDL-cholesterol, and malondialdehyde concentrations }\end{array}$ & $(52,53)$ \\
\hline Antimicrobial & $\begin{array}{l}\text { Aqueous and } \\
\text { ethanolic }\end{array}$ & In vitro & $\begin{array}{l}\text { Escherichia coli, Staphylococcus aureus, Aspergillus niger and Candida } \\
\text { albican }\end{array}$ & $(43)$ \\
\hline Antihypertensive & Aqueous & In vitro & $\begin{array}{l}\text { Angiotensin-I-converting enzyme (ACE) and cisplatin-induced } \\
\text { malonylaldehyde (MDA) production }\end{array}$ & (54) \\
\hline Hepatoprotective & Aqueous & $\begin{array}{l}\text { In vitro and in } \\
\text { vivo }\end{array}$ & $\begin{array}{l}\text { Aspartate aminotransferase (AST), alanine aminotransferase (ALT) in } \\
\text { serum, and glutathione (GSH), superoxide dismutase (SOD), } \\
\text { malondialdehyde (MDA) }\end{array}$ & (49) \\
\hline Neuroprotective & Aqueous & In vivo & Modulation of brain cholinergic neurotransmission & $(55)$ \\
\hline Antioxidant & Ethanolic & In vivo & $\begin{array}{l}\text { Increase in glutathione peroxidase (GPx) in the organs (i.e., the } \\
\text { kidney, liver, and brain), GSH was observably increased in the brain, } \\
\text { decrease was observed in reduced GSH in the kidney }\end{array}$ & $(56,57)$ \\
\hline Hypolipidermia & Methanolic & In vivo & $\begin{array}{l}\text { Decrease in the activities of SOD, CAT, glutathione S-transferase } \\
\text { (GST), level of GSH, and a significant increase in the level of } \\
\text { thiobarbituric acid reactive substances (TBARS) }\end{array}$ & (58) \\
\hline Immunomodulatory & Ethanolic & In vitro & Induces cytokine secretion and NO production & $(23,59)$ \\
\hline
\end{tabular}

role in meeting the primary health care of over $80 \%$ of people living in developing countries. For this reason, scientists continue to renew interest in exploring the medicinal and health benefits of various medicinal plants. Reports are on the hypoglycaemic effect of methanol extract of $T$. triangulare in healthy, glucoseloaded and streptozotocin (STZ)-induced diabetic rats (48). For the experiment, the authors harvested leaves of $T$. triangulare from the medicinal garden of MAM
College of Pharmacy, India and the plant identified accordingly. The plant was extracted using methanol according to the known method. For acute toxicity test, the rats were divided into three groups with six animals per group and acute toxicity testing was performed using the doses of 500, 1000 and 2500 $\mathrm{mg} / \mathrm{kg}$ body weight and observed for $24 \mathrm{hr}$ for possible mortality. Effect of methanolic extract of $T$. triangulare was also tested on rats loaded with 
glucose. For this aspect of the experiment, the rats were divided into four groups with six animals per group; one of the groups was a healthy group without glucose load. The authors also tested the effect of methanol extract of $T$. triangulare in the STZ-induced diabetic rat model. The results of the different aspects of the study showed that in the acute toxicity testing, rats treated with the extract did not demonstrate any change in behaviour and no animal died at a dose of $2500 \mathrm{mg} / \mathrm{kg}$ body weight. The extract insignificantly reduced blood glucose level. The blood glucose level of rats loaded with glucose significantly decreased after 60 min. In the diabetic group, extract of T. triangulare significantly reduced the blood glucose level. The hypoglycaemic and antidiabetic effect of extract of $T$. triangulare may be linked to its ability to potentiate insulin release (48).

Reports are also on the evaluation of the effect of T. triangulare leaf flavonoid extract on STZ-induced hyperglycaemia in a rat model (52). For this laboratory-based study, the authors harvested fresh leaf of $T$. triangulare, identified and processed it following known method. Extraction and purification of the flavonoid content of the extract were performed according to the standard method (60). Forty female adult rats divided into 4 groups with 10 animals per group were used for this study. Following feeding and treatment of rats, different biochemical parameters were measured; results indicated that blood glucose level in STZ-induced diabetic rats was significantly reduced following treatment for 21 days with the extract compared to untreated diabetic control. It was also observed that treatment with extract of $T$. triangulare for 21 days significantly improved serum insulin level in STZ-induced diabetic rats compared to the untreated diabetic group. Authors equally observed improved kidney function, lipid profile and antioxidant status following the administration of flavonoid fraction from the extract of $T$. triangulare (27). Also, the inhibitory activity of $T$. triangulare flavonoids on alpha-amylase activity may have played a role in the reduction of carbohydrate hydrolysis and absorption in the intestine, culminating in the reduction of serum glucose levels in this study $(27,61)$.

Scientific reports tend to show that there are over 400 plant species with hypoglycaemic activity $(27,61)$. Sadly, many of these plant species have not been scientifically validated. This, then prompted scientists to investigate the antidiabetic activity of leaves of Talinum spp. in alloxan-induced diabetic rats (62). Leaves of Talinum spp. were collected, identified and validated, extracted according to the previous method. The authors used 30 rats (24 diabetic rats while 6 of the rats belong to the normal group, 5 animals per group). Following the acute oral toxicity test, methanolic extract of Talinum spp. did not elicit any mortality up to $200 \mathrm{mg} / \mathrm{kg}$ and thus safe for human consumption. The authors observed that oral administration of the extract at 200 and $400 \mathrm{mg} / \mathrm{kg}$ for 15 days caused a significant decrease in blood glucose level coupled with improvement in lipid profile. Treatment also increased total protein level, glutathione levels, and reduced lipid peroxidation. Its effect on glucose levels suggests an extra-intestinal action or possibly by insulin-releasing potential. Overall, the results provide a possible explanation for the use of the plant in the traditional treatment and management of diabetes mellitus.

\section{Activity of $T$. triangulare on cerebral function}

Medicinal plants are known to elicit various biological and pharmacological reactions $(4,27,48)$. Growing consumers' demand for traditional food supplements stimulated the interest of scientists to examine the possible effects of $T$. triangulare on cerebral functions in an animal model (63). The results indicate that in the control and treated animals, the cerebrum showed normal histological features and the glial cells normal without vacuolation in the stroma. The relative weight of the brain presents a dose-dependent increment in the treated rats. The level of MDA was significantly reduced in the treated group while catalase activity also increased in the groups treated with extract of $T$. triangulare. The results thus reflect the non-toxic and non-interference of the extract and its potential to protect cellular integrity and normal metabolic processes, demonstrating the potential ability of $T$. triangulare to enhance brain function in an animal model by reducing oxidative stress.

\section{Antibacterial and antifungal activity of $T$. triangulare}

Plants produce diverse chemical compounds to respond to threats from microorganisms, animals and human beings. Despite the rapid progress that has been made in the development of drugs from synthetic sources, extracts of plants continue to play a significant role in the fight against bacterial infections. In testing the antibacterial activity of medicinal plants against selected clinical isolates, collection was made on fresh and healthy leaves of $T$. triangulare from the local vegetable garden (43). Following a proper and scientific identification of the plant, it was extracted using a known method. The authors used microorganisms such as Escherichia coli, Staphylococcus aureus, Aspergillus niger and Candida albicans to assess the antibacterial and antifungal activity of the plant extract. Results indicated that extract of $T$. triangulare inhibited Escherichia coli, Staphylococcus aureus, Aspergillus niger and Candida albicans. The activity of plant extract of $T$. triangulare against bacteria and fungi is related to their phytochemical constituents $(43,46,64)$. Reports are also on antimicrobial activity of methanol extract of $T$. triangulare against five Gram-positive bacteria, two Gram-negative bacteria and two fungi (65).

\section{Antihelmintic activity of $T$. triangulare}

Parasitic infections are known to affect animals, humans as well as plants, affecting productivity and economic well-being. Although, drugs for treating parasitic infection are available, however, they are expensive and have side effects. These factors have prompted researchers and farmers to seek alternative means of treating parasitic infections. Interestingly, medicinal plants seem to be an acceptable alternative in this regard. As part of the exploration of the role of medicinal plants in the treatment of parasitic infections, investigations are on the role of $T$. triangulare in the treatment of earthworms in an in vitro model (70). The authors collected earthworm about $4 \mathrm{~cm}$ in size and performed antihelmintic 
activity on the worms. The earthworms (Lumbricus spp.) were placed in a Petri dish containing various (50, 100 and $200 \mathrm{mg} / \mathrm{ml}$ ) of $T$. triangulare. Five worms were placed in each petri dish and observed for paralysis/death. The number of worms that were paralysed or died was recorded and the result was compared with control (worms without treatment with extract of $T$. triangulare). The authors reported that extract of $T$. triangulare demonstrated an antihelmintic effect by causing the death of the worms at different concentrations of the extract that were used in the experiment.

\section{Antioxidant activity of $T$. triangulare}

Studies have shown that medicinal and aromatic plants are sources of nutrients with many of the ingredients displaying antioxidant activity; thus, offering protection to both animal and human biological systems against cellular damage resulting from the effects of oxidative stress $(4,66-69)$. To assess the antioxidant activity of $T$. triangulare, collection of fresh leaves of $T$. triangulare and assessed their antioxidant activity using standardised methods (65). It was reported that methanol extract of $T$. triangulare displayed scavenging activity against free radicals. The results corroborate with the earlier report (2). Excessive acute or chronic alcohol consumption poses a serious health risk and could culminate into various metabolic disorders in hepatic and extra-hepatic tissues (71). To test the preventive and therapeutic activities of methanol extract of $T$. triangulare leaves against ethanol-induced oxidative stress in an animal model, collection of fresh leaves of $T$. triangulare was made from a local market in Ibadan, Nigeria (72). Following the previous method, the authors identified and prepared methanolic extract of the plant. For the study, 20 male Wistar rats weighing between 120 and $150 \mathrm{~g}$ were used. The animals were randomly grouped into 4 groups (A-D) $(\mathrm{N}=5)$. Animals in groups $A$ and $B$ received saline while the animals in groups $C$ and $D$ received $T$. triangulare extract for 21 days. Following treatment of animals for $12 \mathrm{hr}$, they received a single dose of $70 \%$ ethanol at $12 \mathrm{ml} / \mathrm{bwt}$ to induce oxidative stress. The results showed that ethanol-induced oxidative stress, administration of the plant extract was able to ameliorate the negative effects of ethanolinduced oxidative stress, suggesting that the extract has preventive and therapeutic potential against ethanol-induced oxidative stress.

\section{Gastrointestinal activity of $T$. triangulare}

Medicinal plants are known to demonstrate various pharmacological effects including gastrointestinal effects. To investigate the effect of aqueous root extract of T. triangulare on the gastrointestinal system, fresh root of the plant was collected from a community garden in Lagos, Nigeria, properly identified the plant and followed the previously described extraction method (73). In this experiment, the authors examined three aspects: acute toxicity test, normal intestinal transit and castor oil-induced diarrhoea. For the acute toxicity test, mice were divided into five groups $(\mathrm{N}=5)$ and received 1250 to $10000 \mathrm{mg} / \mathrm{kg}$ of the extract. The other five groups $(\mathrm{N}=5)$ received 125 to $1000 \mathrm{mg} / \mathrm{kg}$ of the extract intraperitoneally. The control animal group received distilled water (1 $\mathrm{ml} / \mathrm{kg})$. All the animals were monitored for possible signs; observed for $2 \mathrm{hr}$ and subsequently for 7 days. The report shows that animals who received oral doses at 2500, 5000 and $10000 \mathrm{mg} / \mathrm{kg}$ elicited 20, 40 and $80 \%$ mortality, respectively. Intraperitoneal administration of the extract at a dose of $125 \mathrm{mg} / \mathrm{kg}$ caused no death but at 250, 500 and $1000 \mathrm{mg} / \mathrm{kg}$, it caused $20 \%, 40 \%$ and $100 \%$ death, respectively. In the normal intestinal transit aspect of the experiment, the authors orally gave extract to overnight fasted mice at a concentration ranging from 50 to $2000 \mathrm{mg} / \mathrm{kg}$ while distilled water served as control (10 ml/kg). After $30 \mathrm{~min}$ of administration of the extract, mice were given standard charcoal meal $(0.2 \mathrm{ml} / \mathrm{kg})$ intragastrically. After 30 min of receipt of the charcoal meal, animals in each treated group were sacrificed and the small intestine was removed. Animals in the charcoal meal group were observed to have traversed about $68.5 \%$ of the total length of the small intestine. Concentrations of extract at 50, 100 and $200 \mathrm{mg} / \mathrm{kg}$ did not generate a significant increase in intestinal propulsion compared to the control. However, at 500, 1000 and $2000 \mathrm{mg} / \mathrm{kg}$, the extract produced significant inhibition of intestinal propulsion. In the castor oil-induced diarrhoea, four hours following the administration of castor oil, the animals in the control group, had copious diarrhoea. Pre-treatment of animals with high doses of the extract (500 to $2000 \mathrm{mg} / \mathrm{kg}$ yielded a dosedependent delay in the onset of diarrhoea, low doses of the extract (50 to $200 \mathrm{mg} / \mathrm{kg}$ ) did not yield a significant effect of the normal intestinal transit (73).

Peptic ulcer is a consequence of an imbalance between aggressive factors such as acid, pepsin, nonsteroidal anti-inflammatory medications and mucosal defence system $(74,75)$. To evaluate the antiulcer activity of $T$. triangulare, leaves were harvested from the local garden at Faculty of Agricultural Sciences, LAUTech, Ogbomoso, Nigeria (75). The plants were scientifically identified, processed, and extracted according to known methods. In the experiment, 28 male Wistar rats weighing between 160 and 180 g were randomly divided into 4 groups (A-D). Group A rats received distilled water, group B represents ulcerated untreated rats, group $\mathrm{C}$ which is the ulcerated group received $20 \mathrm{mg} / \mathrm{bwt}$ omeprazone (standard medication) while group $\mathrm{D}$ which represents ulcerated rats received $100 \mathrm{mg} / \mathrm{kg}$ bwt extract of $T$. triangulare. Distilled and plant extracts were given to the specific groups orally using an orogastric tube for 14 days. The animals were later sacrificed, and performed various tests to evaluate the antiulcer activity of the plant. It was reported that healing was accelerated in the $T$. triangulare extract treat group and authors attributed this to the presence of flavonoids and saponins present in the leaves suggesting that the mechanism of action via the plant accelerated ulcer healing may be related to increased proliferative and angiogenic activities via an antioxidant-dependent pathway.

\section{Pro-vitamins, vitamins and other micronutrients of $T$. triangulare}

Vegetables such as $T$. triangulare are a good source of dietary protein, thus serving as food supplement in 
preventing or managing malnutrition particularly in developing countries where many families and individuals cannot afford meat and fish. The high protein content of these vegetables provides complementary-supplementary amino acids combined with the animal protein needed for proper growth and development. Vegetables are also rich in dietary fibre and $T$. triangulare has been reported to be rich in dietary fibre (about 56\%) (41). It has also been reported that the extract of $T$. triangulare is rich in vitamin C $(41,76)$. Magnesium has been linked to lowering the incidence of coronary heart disease and associated with reducing hyperglycaemia in diabetes mellitus and the leaves of $T$. triangulare are rich in these and other minerals $(77,78)$.

\section{Toxicities of T. triangulare}

In one study to investigate the effect of the leaf extract of $T$. triangulare, its effects were found to be dosedependent, therefore, care should be taken during its use as excessive intake can result in liver and kidney damage and increase its LDL level which could promote damage to a biological system (79). A study shows that a low dose of the extract of $T$. triangulare (100 and $250 \mathrm{mg} / \mathrm{kg}$ body weight) in female and male rats significantly increased the level of serum bilirubin (32). Reports are on the accumulation of heavy metals in soil and $T$. triangulare obtained from different dumpsites in the southern part of Nigeria and noted that the levels range in both soil and $T$. triangulare from $\mathrm{Zn}>\mathrm{Cd}>\mathrm{Ni}>\mathrm{Pb}$ and $\mathrm{Ni}>\mathrm{Zn}>\mathrm{Pb}>\mathrm{Cd}>\mathrm{Fe}$ respectively in that order (80). The authors recommended that indiscriminate dumping of refuse and cultivation of edible vegetables on dumpsite soils should be discouraged due to potential ill health that may be associated with such practice (81).

\section{Conclusion}

Traditional antidiabetic medicinal plants may act as a vital source of new oral hypoglycaemic compounds for development as pharmaceutical agents and could act as dietary supplements to existing therapies. The same could be said of medicinal plants with antibacterial, antifungal, antihelmintic, anticancer, antiulcer and antioxidant activities. The utilization and application of these plants could prevent or retard the progression of various disease conditions. This review examines the therapeutic potentials and pharmacological activities of $T$. triangulare (Jacq.) Willd. The findings reveal the antidiabetic, hypoglycaemic, antiulcer, antimicrobial and antioxidant activities of this valuable plant and should stimulate further research on the bioactive compounds from the plant.

\section{Acknowledgements}

I would like to thank the Cape Peninsula University of Technology (CPUT) and National Research Foundation (NRF), South Africa for financial support.

\section{Conflict of interests}

Author declares that there is no conflict of interest.

\section{References}

1. Martin FW, Ruberte-Meither LS. Edible leaves of the tropic: educational concerns for hunger organization, INC, 1998;1-8.

2. Eleazu CO, Eleazu KC. Bioactive constituents and in vitro antioxidant capacity of water leaf (Talinum triangulare) as affected by domestic cooking. European Journal of Medicinal Plants. 2013;3(4):540-51. https://doi.org/10.9734/EJMP/2013/4577

3. Raskin I, Ribnicky DM, Komarnytsky S. Plants and human health in the twenty first century. Trends in Biotechnology. 2002;20(12):522-53. https://doi.org/10.1016/S0167-7799(02)020802

4. Oguntibeju OO. Medicinal plants and their effects on wound healing in diabetic state. Veterinary World. 2019A;12(5):653-63.

5. Addis G, Abebe D, Urga R. A survey of traditional medicinal plants in Shirka District, Arsi Zone, Ethiopia. Ethiopian Pharmaceutical Journal. 2001;19:30-47.

6. WHO. General guidelines for methodologies on research and evaluation of tradition medicine. WHO Bulletin. 2001;9(8):137882.

7. WHO. National policy on traditional medicine and regulation of herbal medicine-report of WHO Global Survey. 2005;1-168.

8. Aslam MS, Ahmad MS. Worldwide importance of medicinal plants: Current and historical perspectives. Recent Advances in Biology and Medicine. 2016;2:88-93. https://doi.org/10.18639/RABM.2016.02.338811

9. Mertz W. Trace elements and minerals in diabetes. In: Diabetes mellitus and obesity. Brodoff BN, Bleicher SJ (Eds.) Williams \& Wilkins. 1982;343-48.

10. Mohan V, Ramachadran A, Viswanathan M Tropical diabetes. In: The Diabetes Annual. Albert MM, Krall L (Eds.) Amsterdam, Elsevier, 1985;82-92.

11. Kanter Y, Teicher D, Wiener F, Lesman T, Mandelbaum A. Postprandial glucose response to extracts of Poterium spinosum in normal and diabetic rats. In: Lessons from Animal Diabetes. Shafrir E, Renold AE (Eds.) London Libbey. 1984;627-35.

12. Steinmetz EF. Poterium spinose cortex radice. QJ Drug Res. 1964;4:582-88.

13. Rubenstein AH, Leven $\mathrm{NH}$, Elliot GA. Manganese-induced hypoglycaemic. $\quad$ Lancet. 1962;2:1348-51. https://doi.org/10.1016/S0140-6736(62)91022-X

14. Reddy S, King GL. The insulin receptor: an update. In: The diabetes annual 3 Abert MM, Krall LP (Eds). Amsterdam, Elsevier, 1987;449-58.

15. Aja PM, Okaka AN, Onu PN, Ibiam U, Urako AJ. Phytochemical composition of Talinum triangulare leaves. Pakistan Journal of Nutrition.

https://doi.org/10.3923/pjn.2010.527.530 2010;9:527-30

16. Wild S, Rogic G, Green A, Sicree R, King H. Global prevalence of diabetes: estimates for the year 2000 and projections for 2030 . Diabetes Care. 2004;27:1047-53. https://doi.org/10.2337/diacare.27.5.1047

17. American Diabetes Association Economic costs of diabetes in the USA in 2007. Diabetes Care. 2008;31:596-615. https://doi.org/ 10.2337/dc08-9017

18. Leon BM, Maddox TM. Diabetes and cardiovascular disease: epidemiology, biological mechanisms, treatment recommendations and future research. World Journal of Diabetes. https://doi.org/10.4239/wjd.v6.i13.1246 2015;6(13):1246-58

19. Matheus AS, Tannus LR, Cobas RA, Palma CC, Negrato CA, Gomes MB. Impact of diabetes on cardiovascular disease: an update. International Journal of Hypertension. 2013:635789.

20. WHO. WHO global report on diabetes. 2018. (www.who.org).

21. International Diabetic Federation (IDF); 2018. IDF diabetic atlas 8th ed.

22. Cheung BM, Li C. Diabetes and hypertension: Is there a common metabolic pathway? Current Atheroclerosis Reports. 2012;14(2):160-66. https://doi.org/10.1007/s11883-012-0227-2 
23. Liao DY, Chai YC, Wang SH, Chen CW, Tsai MS. Antioxidant activities and contents of flavonoids and phenolic acids of Talinum triangulare extracts and their immunomodulatory effects. Journal of Food and Drug Analysis 2015; 23(2):294-302. https://doi.org/10.1016/j.jfda.2014.07.010

24. Uwah EI, Ndahi NP, Ogugbuaja VO. Study of the levels of some agricultural pollutants in soils and water leaf (Talinum triangulare) obtained in Maiduguri Nigeria. J Appl Sci Environ Sanit. 2009;4:71-78.

25. Kumar A, Prasa MNV, Sytar O. Lead toxicity, defense and associated indicative biomarkers in Talinum triangulare grown hydroponically. 2012;89:1056-65. https://doi.org/10.1016/j.chemosphere.2012.05.070

26. Nyffeler R., Eggli U. Disintegrating Portulacaceae: a new familial classification of the suborder Portulacineae (Caryophyllales) based on molecular and morphological data. Taxon. 2010;59:227-40. https://doi.org/10.1002/tax.591021

27. Oluba OM, Adebiyi FD, Dada AA, Ajayi AA, Adebisi KE, Josiah SJ, Odutuga AA. Effects of Talinum triangulare leaf flavonoid extract on streptozotocin-induced hyperglycaemia and associated complications in rats. Food Science and Nutrition. 2019;7:385-94. https://doi.org/10.1002/fsn3.765

28. warna J, Ravindhran R, Lokeswari TS. Characterization of Talinum triangulare (Jacq.) Willd. germplasm using molecular descriptors. South African Journal of Botany. 2015;97:59-68. https://doi.org/10.1016/j.sajb.2014.12.012

29. Folarin OM, Bamiro FO, Esuoso KO. Distribution of nutritive elements in water leaf (Talinum triangulare) and juice mallow. Global J Pure and Applied Sciences. 2001;7(7):285-89.

30. Oluwole FS, Falade AO, Ogundipe OO. Antinflammatory effect of some common Nigerian vegetables. Nigerian Journal of Physiological Sciences. 2003;18:35-38.

31. Iwalewa EO, Adeyemi CO, Omisore NO, Adebanji OA, Azike CK, Adigun et al. Pro and antioxidant effects and cytoprotective potentials of nine edible vegetables in southwest Nigeria. J Med Fod. 2005;8(4):539-44.

32. Ekpo A, Eseyin O, Kalu N, Jackson O, Edoho EJ. Studies on the biochemical effects of Talinum triangulare in rat. Journal of Pharmacology and Toxicology. 2007;2(3):300-03. https://doi.org/10.3923/jpt.2007.300.303

33. Seetharami RT, Ramarao NB, Prasanthi S. In: Irfan Alikhan and Atiya Khanum (eds.) Herbal Remedies for Diabetes: Ethnomedicine and Human Welfare-III. Hyderabad, Ukaaz publications. 2004, 44

34. Daniel KA. Traditional vegetables in Ghana. In: Traditional African vegetables promoting the conservation and use of underutilized and neglected crops. 16th proceeding of IPGRI. Guarantor, L (Ed.), 2004; IPGRI Rome, Italy.

35. Siemonsma JS, K Piluek. Plant resources of South East Asia No.8 Vegetable. Pudoc Scientific Publishers, Wageningen. 1993;pp 141- 48

36. ACB. Checklist of medicinal plants in South East Asia. Asean Centre for biodiversity, 2004; pp.T-Z.

37. Mensah JK, Okoli RI, Ohaju-Obodo JO, Eifediyi K. Phytochemical, nutritional and medical properties of some leafy vegetables consumed by Edo people of Nigeria. African Journal of Biotechnology. 2008;7(14):2304-09.

38. Ogunlesi M, Okiei W, Azeez L, Obakachi V, Osunsanmi M, Nkenchor G. Vitamin C contents of tropical vegetables and foods determined by voltammetric and titrimetric methods and their relevance to the medicinal uses of the plants. International Journal of Electrochemical Sciences. 2010;5:105-15.

39. Egwin PO. Biochemical rating system for vegetable food protein. Nigerian Journal Science. 1979;13:323-29.

40. Akachuka CO, Fawusi MAO. Growth characteristics, yield and nutritional value of waterleaf, Talinum triangulare (Jacq.) Willd. in a semi-wild environment. Discovery \& Innovation. 1995;7:163-72.

41. Agunbiage SO, Ojezele MO, Alao OO. Evaluation of the nutritional, phytochemical compositions and likely medicinal benefits of Vernonia amygdaline, Talinum triangulare and Ocimum basilicum leafy vegetables. Adv Biol Res. 2015;9(3):15155.
42. Reddi ST, Naidu RB, Prasanthi S In: Herbal remedies for diabetes: Ethnomedicine and Human Welfare-111 Hyderadad, Ukaaz Publications. 2004;44

43. Nudche MU, Otaka CL. Phytochemcial screening and antimicrobial activity of Talinum triangulare Willd., Ocimum gratissimum L., Chromolaena odorata L. and Aloe vera (L.) Burm. f. International Research Journal of Pharmaceutical and Biosciences. 2019;10(2):23-29.

44. Agboola BE, Ologhobo AD, Adejumo IO, Adeyemo GO. Response of broiler chickens to Carica papaya and Talinium triangulare leaf meal under normal and subnormal diets. Annual Research and Review in Biology. 2018;1-7.

45. Alector VA, Adeogun OA. Nutrients and anti-nutrient components of some tropical leafy vegetables. International Journal of Food Chemistry. 1995;54(4):375-79.

46. Ezekwe MO, Besong SA, Igbokwe PE Beneficial influence of purslane and waterleaf supplement to human. Federation of American Societies for Experimental Biology. 2001;16(4):A639.

47. Adefolaju GA, Ajao MS, Olatunji LA, Enaibe BU, Musa MG. Hepatoprotective effect of aqueous extract of water leaf (Talinum triangulare) on carbon tetrachloride-induced liver damage on Wistar rats. The Internet Journal of Pathology. 2009;8(1):1-9

48. Babu R, Rao PR, Rao PM, Kanth JMK, Srinivasulu M, Hareesh V. Hypoglycaemia activity of methanolic extract of Talinum triangulare in normal and streptozotocin-induced diabetic rats. Journal of Applied Pharmaceutical Science. 2012;2(5):197-201.

49. Liang D, Zhou Q, Gong W, Wang Y, Nie Z, Li J et al. Studies on the antioxidant and hepatoprotective activities of polysaccharides from Talinum triangulare. Journal of Ethnopharmacology. 2011;136(2):316-21. https://doi.org/10.1016/ j.jep.2011.04.047

50. kewuchi CC, Ikewychi JC, Ifeanacho MO. Bioactive phytochemicals in an aqueous extract of the leaves of Talinum triangulare. Food Science and Nutrition. 2017;5:696-701. https:// doi.org/10.1002/fsn3.449

51. Prabha DS, Dahms HU, Malliga P. Pharmacological potentials of phenolic compounds from Propsopis spp. A review. Journal of Coastal Life Medicine. 2014;2(11):918-24.

52. Xu W, Zhou Q, Yin JJ, Yao Y, Zhang JL Anti-diabetic effects of polysaccharides from Talinum triangulare in streptozotocin (STZ)-induced type 2 diabetic male mice. International Journal of Biological Macromolecules. 2015;72:575-79. https://doi.org/10.1016/j.ijbiomac.2014.09.011

53. Kanth JK, Hareesh V. Hypoglycemic activity of methanolic extract of Talinum triagulare leaves in normal and streptozotocin induced diabetic rats. Journal of Applied Pharmaceutical Science. 2012;2(5):197.

54. Oboh G, Akinyemi AJ, Adeleye B, Oyeleye SI, Ogunsuyi OB, Ademosun AO, Ademiluyi AO, Boligon AA. Polyphenolic compositions and in vitro angiotensin-I-converting enzyme inhibitory properties of common green leafy vegetables: a comparative study. Food Science and Biotechnology. 2016;25(5):1243-49. https://doi.org/10.1007/s10068-016-0197-1

55. Ebuehi OA, Ajagun-Ogunleye MO. Neurochemical impact of the aqueous extract of Vernonia amygdalina and Talinum triangulare on learning and memory in male Wistar rats. 2017.

56. Afolabi OB, Oloyede OI. Antioxidant properties of the extracts of Talinum triangulare and its effect on antioxidant enzymes in tissue homogenate of Swiss albino rat. Toxicology International. 2014;21(3):307. https://doi.org/10.4103/0971-6580.155377

57. Uraku AJ, Uraku OH, Onuoha SC, Edwin N, Ezeali C, NN Ezeani, OU Obasi, NV Ogoh EJ Dingwoke, OF Orinya, FN Nweke, PE Ozioma, BN Enemchukwu. Protection by methanol and flavonoid-rich leaf extracts of Talinum triangulare against leadinduced toxicity in rats. Research Journal of Medicinal Plants. 2020;14:125-32. https://doi.org/10.3923/rjmp.2020.125.132

58. Olorunnisola OS, Adetutu A, Afolayan AJ, Owoade AO. Effect of methanolic leaf extract of Talinum triangulare (Jacq.). Willd. on biochemical parameters in diet induced dyslipidemia wistar rats. Pharmacognosy Magazine. 2016;12(48):333.

59. Yeh SH, Hsu WK, Chang ZQ, Wang SH, Hsieh CW, Liou GG, Lee $\mathrm{HB}$, Jiang BH, Tsou HK, Tsai MS. Purification and 
characterization of fractions containing polysaccharides from Talinum triangulare and their immunomodulatory effects. Processes. 2021;9(4):709. https://doi.org/10.3390/pr9040709

60. Ghharekhani M, Raflee Z, Ghorbani M, Jafari S. Open vessel microwave system for extraction of analytes from medicine plants. 2009; Iran Patent No 59321.

61. Oboh G, Ademiluyi AO, Akinyemi AJ, Henle T, Saliu JA, Schwarzenbolz U. Inhibitory effect of polyphenol-rich extracts of jute leaf on key enzymes linked to type 2 diabetes and hypertension in vitro. Journal of Functional Foods. 2012;4(2):450-58. https://doi.org/10.1016/j.jff.2012.02.003

62. Rao TN, Kumaranppan CT, Lakshmi MS, Mandal SC. Antidiabetic activity of leaves of Talinum fortulaciforum in allozan-induced diabetic rats. Pharmacologyonline. 2007;2:40717.

63. Ofusori DA, Adelakun AE, Ayoka AO, Oluwayinka OP, Omotoso EO, Odukoya SA. Adeyemi DA Waterleaf (Talinum triangulare) enhances cerebral functions in Swiss albino mice. J Neur Sci. 2008;25(4):239-46.

64. Abba PE, Joshua PE, Ezeonuogu FC, Ezeja MI, Omojo VU, Umeakuana PU Possible antidiarrhoeal potential of ethanol leaf extract of Chromolaena odorata in castor oil-induced rats. Journal of Complementary and Integrative Medicine. 2015;12(4):301-06.

65. Chetia J, Upadhyaya S, Bora DK. Screening of phytochemicals, antioxidant and antimicrobial activity of some tea garden weeds. International Journal of Pharmaceutical Sciences Review and Research. 2014;26(1):193-96.

66. Ogbonnaya EC, Chinedum EK. Bioactive constituents and in vitro antioxidant capacity of water leaf (Talinum triangulare) as affected by domestic cooking. European Journal of Medicinal Plants. 2013;3(4):540-51. https://doi.org/10.9734/EJMP/2013/4577

67. Oguntibeju OO. Medicinal plants with anti-inflammatory activities from selected countries and regions of Africa. Journal of Inflammation Research. 2018;11:307-17. https://doi.org/10.2147/JIR.S167789

68. Oguntibeju OO. Anti-diabetic, anti-inflammatory, anti-bacterial, anti-helminthic, antioxidant and nutritional potentials of Musa paradisiaca. Asian Journal of Pharmaceutical and Clinical Research. 2019b;12(10):1-5.

69. Oguntibeju OO, Aboua Y, Goboza M. Vindoline-a natural product from Catharanthus roseus reduces hyperlipidemia and renal pathophysiology in type 2 diabetes. Biomedicines. 2019;7:1-23. https://doi.org/10.3390/biomedicines7030059

70. Adeola AO, Osho IB, Adewole SO, Olofintoye LK. In vitro antihelmintic activity of three medicinal plants. Journal of Nursing and Health Sciences. 2016;1(7):55-63.

71. Lieber CS. Ethnic and gender differences in ethanol metabolism Alcoholism: Clinical and Experimental Research. 2000;24(4):41718. https://doi.org/10.1111/j.1530-0277.2000.tb02003.x

72. Airaodion AI, Akinmolayan JD, Ogbuagu EO, Esonu CE, Ogbuagu U Preventive and therapeutic activities of methanolic extract of Talinum triangulare leaves against ethanol-induced oxidative stress in Wistar rats. International Journal of Bioscience and Biotechnology. 2019;11(7):85-96.

73. Adeyemi O, Oyeniyi O, Mbagwu H, Jackson C. Evaluation of the gastrointestinal activity of the aqueous root extracts of Talinum triangulare. Research in Pharmaceutical Biotechnology. 2011;3(4):61-67.

74. Hoogerwerf WA, Pasricha PJ. Agents used for control of gastric acidity and treatment of peptic ulcers and gastroesophageal reflux disease. In: Hardman JG, Limbird LE (Ed). Pharmacological Basis of Therapeutics 10th ed. New York: Tata Mc Graw Hill. 2001;1005-19.

75. Ajayi AF, Folawiyo AM, Salami TA. Ulcer healing mechanism of ethanolic extract of Talinum triangulare in male wistar rats. UK J Pharma and Bioscience. 2016; 4(4):41-50. https://doi.org/10.20510/ukjpb/4/i4/110647

76. Mnazava NA. Comparing nutritional values of exotic and indigenous vegetables: In African indigenous vegetables workshop. Proceedings, Limbe Cameroon. Schippers RR and Budo L (Eds), Chatham, UK pp: 1997;1-4.

77. Kartzwell P. Nutrition facts to help consumers eat smart, FDA consumer. 1993: 1-6.

78. Fallon SAF, Enig MG Nourishing traditions 2nd Washington DC, New Trends Publishing. 2001, 11.

79. Igbayiola YD, Morakinyo AO, Ewetayo AW, Oyabambi AO, Saka WA. Biochemical and antioxidant effects of Talinum triangulare in female Sprague-dawley rats. The International Journal of Basic and Applied Physiology. 2017;6(1),22.

80. Ebong GA, Enik HS, Johnson AS. Heavy metals accumulation by Talinum triangulare grown in waste dumpsites in Uyo metropolis, Akwa Sate, Nigeria. Journal of Applied Sciences. 2007;7(10):404-09. https://doi.org/10.3923/jas.2007.1404.1409

81. Organization for Economic Co-operation and Development (OECD) Guidelines for testing of chemicals-acute oral toxicity, OECD Paris. 2002.

Additional information

Peer review information: Plant Science Today thanks Sectional Editor and the other anonymous reviewers for their contribution to the peer review of this work.

Reprints and permissions information is available at https://horizonepublishing.com/journals/index.php/PST/open_access_policy

Publisher's Note: Horizon e-Publishing Group remains neutral with regard to jurisdictional claims in published maps and institutional affiliations.

To cite this article: Oguntibeju O O, Okaiyeto K. Therapeutic potentials and pharmacological properties of Talinum triangulare (Jacq.) Willd. in the treatment and management of diabetes mellitus and other conditions. Plant Science Today. 2021;8(4):1098-1106. https://doi.org/10.14719/pst.2021.8.4.1181

Plant Science Today, published by Horizon e-Publishing Group, is covered by Scopus, Web of Science, BIOSIS Previews, Clarivate Analytics, etc. See https://horizonepublishing.com/journals/index.php/PST/indexing_abstracting 